\title{
The Practice of Conflict Management in Construction Projects in Kenya
}

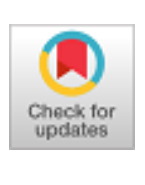

\author{
Samuel Kiilu Mbatha, Ahmad Omar Alkizim, Titus Kivaa Mbiti
}

\begin{abstract}
Conflicts in construction projects seem an increasingly prevalent phenomenon in Kenya, perhaps because of the projects' uncertainty, complexity, and diversity of participants. Management of these conflicts remains ineffective, an occurrence that creates a major obstacle to the success of project implementation, usually leading to an increase in project cost, delayed project completion, and in worst cases suspension of the project. A review of literature has revealed the negative role played by conflict on project success. This study sought to investigate the practice of conflict management in construction projects in Kenya to develop a schematic framework for managing conflicts, using project harmony potential as a measure of the availability of conflicts or their lack in construction projects. The study adopted a cross-sectional research design. Construction projects registered with NCA in the last five years within Nairobi and having the embedded unit of analysis of project participants under this study were sampled using the cluster method. Questionnaires were administered to project developers, contractors, and consultants working in consultancy or contractor firms randomly sampled. The study used inferential analysis of bivariate Pearson's correlation and Regression analysis to determine the significant factors affecting the project harmony potential as well as establish a predictive model. The study demonstrated that there was a positive and statistically significant linear relationship between project harmony potential and delay management, project team partnering orientation, direct provisions for conflict management in the Project Handbook, promptness of Monitoring and Evaluation work, CPM (Construction Project Manager) technical experience, and communication plan. These factors were considered to be critical factors for the project harmony potential for construction projects in Kenya. A model was established using these variables and was found to explain $69.1 \%$ of the project harmony potential. The developed model will be useful in predicting the harmony potential of a project during implementation.
\end{abstract}

Keywords: Conflict, Conflict Management Strategies, Project harmony potential.

\section{INTRODUCTION}

Construction projects are unique and cover a wide range of products and expertise conducted in an environment that is

Manuscript received on March 09, 2021.

Revised Manuscript received on March 15, 2021

Manuscript published on March 30, 2021

* Correspondence Author Management, Jomo Kenyatta University of Agriculture and Technology (JKUAT), Juja, Kenya.

Dr. Ahmad Omar Alkizim, Department of Construction Management, School of Architecture and Building Sciences (SABS, Jomo Kenyatta University of Agriculture and Technology (JKUAT), Juja, Kenya.

Dr. Titus Kivaa Mbiti, Department of Construction Management, School of Architecture and Building Sciences (SABS, Jomo Kenyatta University of Agriculture and Technology (JKUAT), Juja, Kenya.

(c) The Authors. Published by Blue Eyes Intelligence Engineering and Sciences Publication (BEIESP). This is an open access article under the CC BY-NC-ND license (http://creativecommons.org/licenses/by-nc-nd/4.0/)
Mr. Samuel Kiilu Mbatha*, Student, Masters in Construction Project

profit-oriented and commercially sensitive. The execution of these projects is characterized by the interaction of different project participants interrelating to create an organization. The project team may, depending on the type and method of procurement used include, among others, the client/financier, project manager, consultants (architect, structural and service engineers, quantity surveyor, etc.), general contractor, and subcontractors, interacting as a unit within the project team and as individuals or as sub-units within the project team and as individuals within the project team, or as sub-units of the project team, with units outside the project team that may include, but are not limited to, government agencies, public institutions, financial organizations, the community or areas within which such projects are carried out. These project participants form a temporary project coalition in such a set-up, which is recognized by Murray et. al (1999) as cited in Femi (2014) as having a complex set of interrelated relationships created by the interaction of these project participants, hence the need for Project Manager skills in collaboration and collaboration between participants in time coordination, effective communication, and resource management for a successful project. Several scholars such as Boddy (2002a) and Harmon (2003), maintain that conflict is an inevitable by-product of organizational operations in a project environment. (Boddy, 2002a) attribute this to be caused by the fact that despite the project team drawing from different backgrounds and knowledge in different fields, each project participant has their objectives, views, and perspectives which at times could conflict with the general objectives of the organization. Yale and Hardcastle (2003) unwrapped a striking rise in conflicts and disputes in several countries' construction industry in a report on the causes of conflicts and disputes in the Hong Kong construction industry. These conflicts were found out to contribute to high attendance costs both direct costs, including the costs for lawyers, claims consultants, and complete delay compensations, and indirect costs including decadence of working relationships, mistrust amongst the participants, deteriorating teamwork, and arising poor workmanship standards. These factors undermine the successful execution of a project. The situation is indifferent from the Kenyan construction industry.The key factors that cause conflicts leading to project delays in Kenyan high-rise buildings are related to the project participants and their interrelationships, the process, and the project implementation environment, mainly the problem and conflicts management approach used. These conflicts breed a deleterious project environment,

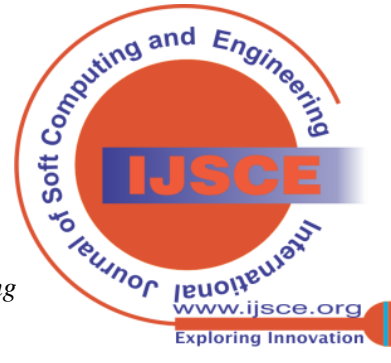




\section{The Practice of Conflict Management in Construction Projects in Kenya}

foster distrust, and subvert the cooperative essence of the construction process, sometimes leading to legal issues. (Talukhaba, 1999). However, effective conflict planning and control demand an in-depth understanding of their nature and sources, to set up mechanisms and strategies in the most timely and cost-effective way for their effective detection and management of the project is to be successful.

\section{LITERATURE REVIEW}

\subsection{Conflict defined}

Conflict is a phenomenon of opposition, dissonance, or incompatibility of views, interests, impressions, beliefs, notions, behavior, or goals between and among individuals [Ejohwomu et al., 2016; Kassab et al, 2010].

\subsubsection{Classification of Conflicts}

The effect of conflict is a highly subjective measure according to which party's point of view is taken. According to, Vaux (2014) conflicts can generally be divided to form two major categories, each with a different effect on project execution

Table 2.1: Relationship and Task conflict

\begin{tabular}{lll}
\hline Measurement & $\begin{array}{l}\text { Relationship } \\
\text { conflict }\end{array}$ & Task conflict \\
\hline
\end{tabular}

\begin{tabular}{lcll}
\hline $\begin{array}{l}\text { Focus } \\
\text { conflict }\end{array}$ & of & $\begin{array}{l}\text { Interpersonal } \\
\text { incompatibilities }\end{array}$ & Task at hand \\
$\begin{array}{l}\text { Cognitive } \\
\text { or }\end{array}$ & Emotional in nature & Cognitive in nature
\end{tabular}

Emotional

Performance Performance is diminished at all levels

Performance is enhanced in the medium range and decreased at low and high conflict levels.

Organizational Dysfunctional at all view levels

Outcomes Decreased quality of decision, group solidarity, and commitment

Beneficial appropriate levels Increased decision quality, team cohesion, and innovation

\section{Source: (Adapted from Vaux, 2014)}

2.1.2 The spectrum of conflicts in construction projects

When not amicably managed, conflict can collapse relationships between project participants with a consequence of delayed projects and projects completed outside the original objectives and goal. Conflicts in construction projects are unprofitable very expensive to maintain as they affect the interests of many parting in the project undertaking evidenced by reduced profits and gains (Ntiyakunze, 2011)

In construction projects, it becomes very necessary to address possible areas of conflict failure to which can result in a high level of conflict, sometimes progressing into disputes. Conflict conditions rely on goals, strategies, policies, approaches, and personalities that can lead to disputes and litigation, and therefore time extensions, and increased costs (Loosemore, 2000; Harmon, 2003). In their risk, conflict, claim, and dispute continuum model, Acharya, et al, (2006) argue that a conflict can be managed, the requests of a claim can be controlled, and a dispute, which could lead to litigation, can be avoided.

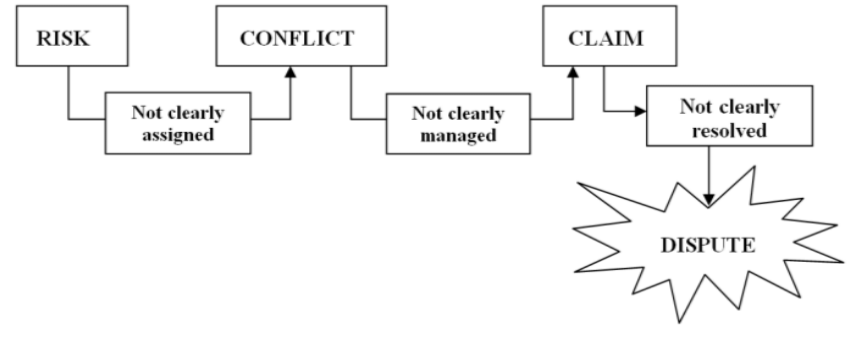

Figure 2.1: Risk, Claim and Dispute continuity Source: (Acharya, et al. 2006)

2.1.3 Project Harmony Potential

Project harmony was described by Puttapalli and Vuram (2012) as being concerned with the reciprocal relationship between the management team and staff regarding the terms and conditions of employment at the workplace. This study used project harmony metaphorically to refer to a situation of the total absence of conflicts in the construction project, through effective conflict management systems, ultimately translating to a successfully performed project. It is a state where employees have a stable and cooperative working relationship that contributes to improved output. (Wobodo, 2019). Management researchers like (Puttapalli and Vuram (2012), Okaka (2019), and Wobodo (2019) define the performance level of a project by the completeness of a project within a given time and budget allocation, mutual trust, contribution of the project to the strategy of the organization, customer satisfaction, and employee participation as the key performance indicators.

\section{OBJECTIVES OF THE STUDY}

- To describe project harmony potential for construction projects in Kenya.

- To explore the practice of conflict management in construction projects in Kenya.

- To evaluate significant factors that influence project harmony potential in construction projects.

- To explain the relationship between project harmony potential and its influencing factors.

- To formulate a framework for managing conflicts in construction projects.

\section{RESEARCH METHODOLOGY}

This research used a quantitative approach. The research focused on understanding conflict management situations in construction projects in Kenya. Based on the argument raised by Mugenda (2008), Creswell (2009), and Bryaman (2012), As quantitative data on multiple variables were collected during the same period, this study can be categorized as a survey research design. Survey research entails a cross-sectional design in which data is collected at a single point and through a questionnaire or formal interview, and seeks to measure the issues, circumstances, and problems of social phenomena that are present in society (Bryman, 2012). The researcher used both manual and electronic questionnaires to collect data from the target population.

The research site for the study was Nairobi County.

Published By:

Blue Eyes Intelligence Engineering and Sciences Publication

(C) Copyright: All rights reserved.

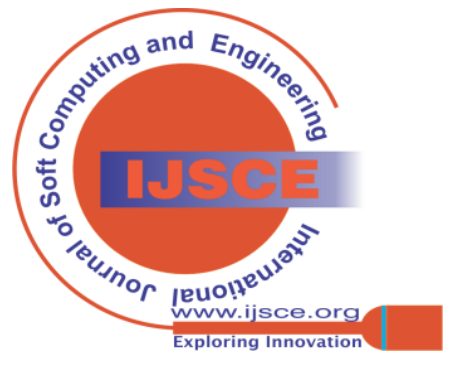


The criterion for selecting respondents was their technical expertise in the construction industry, taking into account the scale of the project. The target population comprised respondents randomly selected from 30 consulting firms and 128 contracting firms registered as NCA 1 to NCA 5 within this geographical scope. These have been considered to be influential in project delivery because they are the people with the roadmap to construction project harmony, hence their ability to produce valuable and varied knowledge on conflict management practices in Kenya's construction projects.

The demographic of consulting firms were drawn from the Association of Consulting Engineers of Kenya (ACEK) and the Nairobi-based Architectural Association of Kenya (AAK). Data obtained was analyzed using the Statistical Package for Social Scientists (SPSS v.21).

\section{RESEARCH FINDINGS}

\subsection{Respondents' Response Rates}

Of a total of 158 questionnaires administered to consultant and contractor firms both manually and electronically, 122 were returned. The respective response rate from consultancy and construction firms was $80 \%$ and $77 \%$.

Table 4.1: Response rate

\begin{tabular}{lccc}
\hline Stakeholders & & $\begin{array}{c}\text { No of } \\
\text { questionnaires }\end{array}$ & $\begin{array}{c}\text { Response } \\
\text { Rate (\%) }\end{array}$ \\
\hline $\begin{array}{l}\text { Consultancy } \\
\begin{array}{l}\text { Building } \\
\text { firms }\end{array}\end{array}$ & $\begin{array}{c}\text { firms } \\
\text { contractor }\end{array}$ & 30 & 80 \\
\hline TOTAL & & 128 & 77 \\
\hline
\end{tabular}

Source: Field survey 2021

4.2 Demographic Profiles of Respondents and their Firms

\subsubsection{Role of the Respondent in the Firm}

The role of the respondents in the firm in descending order are; Construction manager at $23.0 \%$, Quantity surveyor at $19.7 \%$, Construction project manager at $18.0 \%$, Contractor at $17.2 \%$, Architect at $8.2 \%$, Site agent at $6.6 \%$, other at 4.9 , and civil \& structural engineer at $2.5 \%$. The category of "Others" produced a variety of options including; an electrical engineer, a site engineer, a Quality Assurance Analyst, and an accountant. Whereas nearly all building sites have foremen in charge of diverse trades or indeed a general foreman in accountable of all other foremen, a low recurrence was due to the longing to generally lock in mostly academically competent persons to respond to the questionnaire. An architect as a role had the least frequency conceivably since most contractors in Kenya rarely engage in design work because the conventional design-bid-build where the contractor is engaged when all the design work has been accomplished is the most prevalent procurement method in the country.

Table 4.2: Role of respondents in the project

\begin{tabular}{lll}
\hline Role of respondents & $\mathbf{N}$ & Percent \\
\hline Construction project manager & 22 & $18.0 \%$ \\
Architect & 10 & $8.2 \%$ \\
Civil \& structural engineer & 3 & $2.5 \%$ \\
Construction manager & 28 & $23.0 \%$ \\
Quantity surveyor & 24 & $19.7 \%$ \\
Contractor & 21 & $17.2 \%$ \\
Site agent & 8 & $6.6 \%$ \\
\hline
\end{tabular}

\begin{tabular}{lll}
\hline Other & 6 & $4.9 \%$ \\
\hline Total & 122 & $100.0 \%$ \\
\hline
\end{tabular}

Source: Field survey 2021

\subsubsection{Respondent's area of technical training}

The rate of the respondents based on their area of training, in descending order, are Construction Management at $25.4 \%$, Quantity surveying at 21.3\%, Project management at $16.4 \%$, Architecture at $13.1 \%$, Building technology at $9.8 \%$, Civil \& structural engineering at 7.4\%, Electrical engineering at $3.3 \%$, Economics at $2.5 \%$ and Accounting at $0.8 \%$. In this research, the majority of respondents had background training in a construction-related area, hence a better understanding of project execution and oversite process.

\subsubsection{Experience in the industry}

As shown in Fig.4.1 below, the respondents had a large number of years of experience in the construction industry. This indicated the degree of respondents' exposure to conflict management. In descending order, the percentage level of experience of the respondents is; $11-15$ years at $41.3 \%$, Over 15 years at $38.8 \%, 6-10$ years at $14.9 \%$, and Less than 5 years at $5.0 \%$.

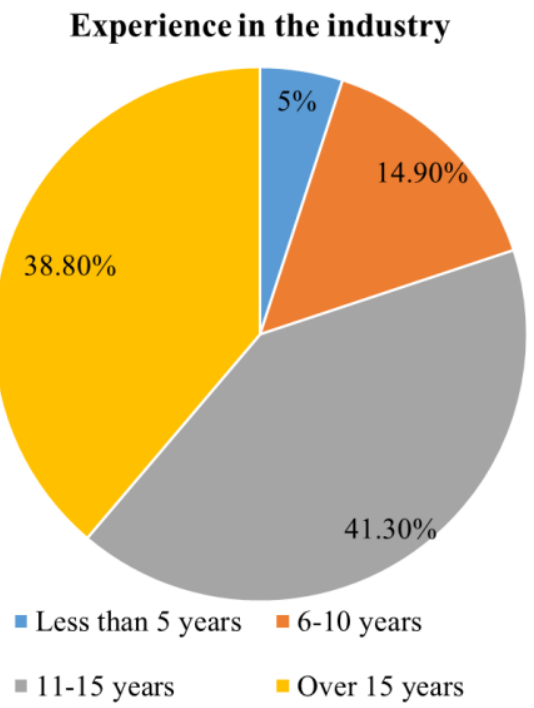

Fig. 4.1 Industry experience of respondents

Source: Field survey 2021

This resulted in a mean experience of 12.51 years as shown in Table 4.3 below.

Table 4.3 Mean Experience of respondents

\begin{tabular}{cccc}
\hline $\begin{array}{c}\text { Experience } \\
\text { (years) }\end{array}$ & $\begin{array}{c}\text { Mid value } \\
(\mathbf{X})\end{array}$ & $\begin{array}{c}\text { Frequency } \\
(\mathbf{F})\end{array}$ & FX \\
\hline Less than 5 & 2.5 & 5 & 12.5 \\
$6-10$ & 8 & 14.9 & 119.2 \\
$11-15$ & 13 & 41.3 & 536.9 \\
Over 15 & 15 & 38.8 & 582 \\
\hline Total & $\mathbf{1 0 0}$ & $\mathbf{1 2 5 0 . 6}$ \\
Mean Years of experience $=\boldsymbol{\Sigma} \boldsymbol{F X / \boldsymbol { \Sigma } F = 1 2 . 5 1}$ & $(\mathbf{1 2 5 1 / 1 0 0 )}$ \\
\hline
\end{tabular}

Source: Field survey 2021

This was an advantage to the study as the respondents were well versed with the conflict management process in construction projects through repetitive works in their occupation.

Published By:

Blue Eyes Intelligence Engineering and Sciences Publication (C) Copyright: All rights reserved 


\section{The Practice of Conflict Management in Construction Projects in Kenya}

\subsubsection{Category of Firm}

Construction projects of big magnitudes (over half a billion shillings) usually attract interest from not only local but also foreign contractors. The frequency of the category of firms is shown in fig. 4.2 below.

\subsection{Descriptive statistics}

Source: Field survey 2021

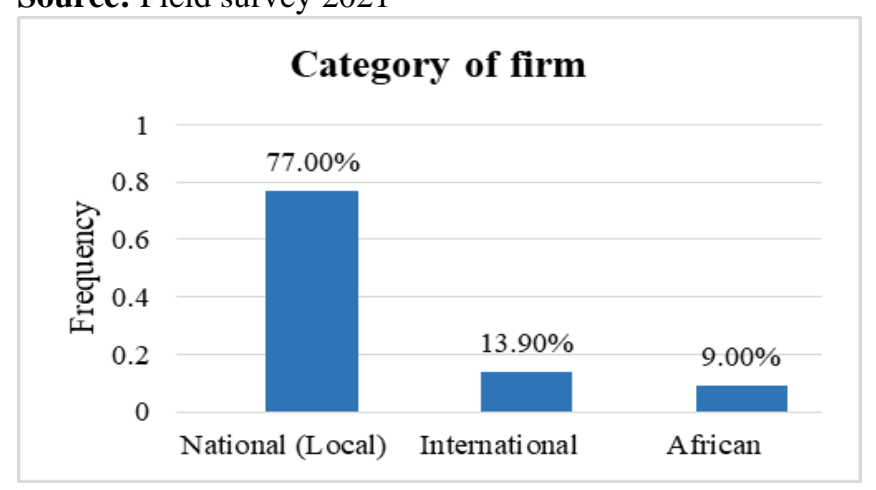

Fig 4.2: Category of Firm
Source: Field survey 2021

The research findings showed that local firms in the construction industry predominated. This meant that the outcomes of this study would comfortably represent local corporations' perspectives and stance on conflict management.

Table 4.4: Variable descriptive

\begin{tabular}{|c|c|c|c|c|c|}
\hline Variable & $\mathbf{N}$ & Minimum & Maximum & Mean & $\begin{array}{c}\text { Std. } \\
\text { Deviation }\end{array}$ \\
\hline Project harmony potential & 97 & 3.18 & 4.48 & 3.82 & 0.275 \\
\hline Delay management & 121 & 1.5 & 5.0 & 3.07 & 0.881 \\
\hline Project suitability by environment & 118 & 2.0 & 5.0 & 3.44 & 0.724 \\
\hline Project team partnering orientation & 121 & 1.5 & 5.0 & 3.72 & 0.903 \\
\hline $\begin{array}{l}\text { Direct provisions for conflict management in the } \\
\text { Project Handbook }\end{array}$ & 120 & 3.0 & 5.0 & 4.17 & 0.640 \\
\hline Promptness of Monitoring and Evaluation work & 122 & 3.5 & 5.0 & 4.44 & 0.488 \\
\hline Technical opinions/Approaches & 120 & 2.0 & 5.0 & 3.99 & 0.828 \\
\hline CPM technical experience & 119 & 1.0 & 4.5 & 2.90 & 0.872 \\
\hline $\begin{array}{l}\text { Expertise of the CPM on psychology and } \\
\text { criminology }\end{array}$ & 122 & 1.0 & 4.5 & 2.61 & 0.883 \\
\hline Clear communication plan & 114 & 3.0 & 4.5 & 3.68 & 0.494 \\
\hline Personality management & 119 & 1.0 & 4.5 & 2.82 & 0.778 \\
\hline
\end{tabular}

The research revealed that the harmony potential for all the projects had a mean value of 3.82 meaning that the process of conflict management was successful on average. While the results of the descriptive for the predictor variables implied some level of success on some aspects like Promptness of monitoring and evaluation, and the use of the direct provisions for conflict management in the project handbook, as explained by a mean of 4.44 and 4.17 respectively, other variables had a mean ranging between 2.61 to 3.99 implying a need to improve on the conflict management process to achieve a more harmonious project.

\subsection{Correlation analysis}

Bivariate Pearson's correlation analysis was used to establish the strength, significance, and direction of the relationship between the dependent variable and independent variables. This relationship between the variables was statistically explored by use of the correlation coefficients.

There was a strong positive linear and statistically significant relationship between promptness of Monitoring and Evaluation work and Project harmony potential as explained by Pearson's correlation coefficients ( $r$ ) and $p$-values (p) of $r=0.729$; $p$-value $<0.001$ ), direct provisions for conflict management in the Project Handbook and Project harmony potential, $r=0.693$; $\mathrm{p}$-value $<0.001$, and CPM technical experience and Project harmony potential, $\mathrm{r}=$ 0.503; p-value $<0.001$. There was a strong positive linear and statistically significant relationship between promptness of Monitoring and Evaluation work and Project harmony potential as explained by Pearson's correlation coefficients (r) and p-values (p) of $\mathrm{r}=0.729$; $\mathrm{p}$-value $<0.001$ ), direct provisions for conflict management in the Project Handbook and Project harmony potential, $r=0.693$; $p$-value $<0.001$, and CPM technical experience and Project harmony potential, $\mathrm{r}=0.503$; $\mathrm{p}$-value $<0.001$. There was a positive and significant relationship between clear communication plan and project harmony potential as evidenced by $\mathrm{r}=0.338$; $\mathrm{p}$-value $=0.001$.

There was also a positive and significant relationship between project team partnering orientation and project harmony potential $(\mathrm{Y}), \mathrm{r}=0.279$; $\mathrm{P}$-value $=0.006$. 
Table 4.5: Pearson's correlation coefficient between the project harmony potential and the various determinants

\begin{tabular}{|c|c|c|c|c|c|c|c|}
\hline & & PHP & PO & DP & ME & $\overline{T E}$ & $\mathbf{C P}$ \\
\hline \multirow[t]{2}{*}{ PHP } & $\begin{array}{c}\text { Pearson } \\
\text { Correlation }\end{array}$ & 1 & $0.279 * *$ & $0.693 * *$ & $0.729 * *$ & $0.503^{* *}$ & $0.338 * *$ \\
\hline & Sig. (2-tailed) & & 0.006 & 0.000 & 0.000 & 0.000 & 0.001 \\
\hline \multirow[t]{2}{*}{$\mathrm{PO}$} & $\begin{array}{c}\text { Pearson } \\
\text { Correlation }\end{array}$ & & 1 & 0.168 & 0.128 & $0.224 * *$ & 0.020 \\
\hline & Sig. (2-tailed) & & & 0.068 & 0.162 & 0.008 & 0.849 \\
\hline \multirow[t]{2}{*}{ DP } & $\begin{array}{c}\text { Pearson } \\
\text { Correlation }\end{array}$ & & & 1 & $0.608 * *$ & $0.281^{* *}$ & $0.306^{* *}$ \\
\hline & Sig. (2-tailed) & & & & 0.000 & 0.002 & 0.001 \\
\hline \multirow[t]{2}{*}{$\mathrm{ME}$} & $\begin{array}{c}\text { Pearson } \\
\text { Correlation }\end{array}$ & & & & 1 & $0.352 * *$ & $0.325 * *$ \\
\hline & Sig. (2-tailed) & & & & & 0.000 & 0.000 \\
\hline \multirow[t]{2}{*}{$\mathrm{TE}$} & $\begin{array}{c}\text { Pearson } \\
\text { Correlation }\end{array}$ & & & & & 1 & $0.218 * *$ \\
\hline & Sig. (2-tailed) & & & & & & 0.021 \\
\hline \multirow[t]{2}{*}{$\mathrm{CP}$} & $\begin{array}{c}\text { Pearson } \\
\text { Correlation }\end{array}$ & & & & & & 1 \\
\hline & Sig. (2-tailed) & & & & & & \\
\hline
\end{tabular}

** Correlation is significant at the 0.01 level (2-tailed)

Source: Field survey 2021

From the table, $\mathbf{P H P}=$ Project harmony potential

$\mathbf{P O}=$ Project team partnering orientation

$\mathbf{D P}=$ Direct provisions for conflict management in Project Handbook

ME=Promptness of Monitoring and Evaluation

$\mathbf{T E}=\mathrm{CPM}$ Technical experience

$\mathbf{C P}=$ Clear communication plan

\subsection{Regression analysis}

This study used regression analysis to determine whether independent variables predict the dependent variable. Stepwise regression was conducted with the Project harmony potential as the dependent variable and Delay management, Project suitability by environment, Project team partnering orientation, Direct provisions for conflict management in the Project Handbook, Promptness of Monitoring and Evaluation work, CPM technical experience, Technical opinions/Approaches, Expertise of the CPM on psychology and criminology, Clear communication plan, and Personality management as the independent variables.

From the results, the standardized coefficients showed the Independent variables with more impact on the dependent variable and it was found that Promptness of Monitoring and Evaluation (0.457) had more effect on project harmony potential followed by Direct provisions of conflict management in the Project Handbook (0.257), followed by CPM Technical experience (0.180), followed by Clear
Communication plan (0.146), followed by Project team partnering orientation (0.135), and finally, Delay management $(0.125)$. The constant term was found to be 1.408. This implied that holding all other factors constant, project harmony potential increases by 1.408 units.

An optimal model was established with only the significant variables and a coefficient of determination (R2) value of 0.691 meaning that the variables explained $69.1 \%$ of the project harmony potential. The model was found to be good in predicting the project harmony potential of a project, $\mathrm{F}=32.290 ; \mathrm{p}=<0.001$. The optimal regression equation derived can be written as:

$\mathrm{Y}=1.408+\mathrm{0.041X}_{1}+\mathrm{0.038X}_{3}+\mathrm{0.110X}_{4}+\mathrm{0.260}_{5}+$ $\mathrm{0.060X}_{6}+\mathbf{0 . 0 8 5}_{9}$

Where,

$\mathbf{Y}$ - Project harmony potential

$\mathbf{X}_{\mathbf{1}}$ - Delay management

$\mathbf{X}_{3}$ - Project team partnering orientation

$\mathbf{X}_{4}$ - Direct provisions for conflict management in the Project Handbook

$\mathbf{X}_{\mathbf{5}}$ - Promptness of Monitoring and Evaluation work

$\mathbf{X}_{\mathbf{6}}$ - CPM technical experience

$\mathbf{X}_{\mathbf{9}}$ - Clear communication plan

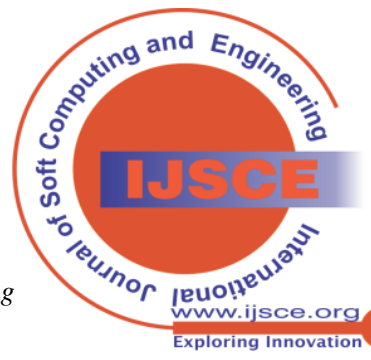


The Practice of Conflict Management in Construction Projects in Kenya

Table 4.6: Linear regression analysis

\begin{tabular}{|c|c|c|c|c|c|c|c|c|}
\hline & \multirow[t]{2}{*}{ Model } & \multicolumn{2}{|c|}{$\begin{array}{l}\text { Unstandardized } \\
\text { Coefficients }\end{array}$} & \multirow{2}{*}{$\begin{array}{c}\text { Standardized } \\
\text { Coefficients } \\
\text { Beta } \\
\end{array}$} & \multirow[t]{2}{*}{ t } & \multirow[t]{2}{*}{ Sig. } & \multirow[t]{2}{*}{$\mathbf{R}^{2}$} & \multirow{2}{*}{$\begin{array}{c}\text { F } \\
\text { (P-value) }\end{array}$} \\
\hline & & B & Std. Error & & & & & \\
\hline \multirow[t]{2}{*}{1} & (Constant) & 2.016 & .191 & & 10.528 & .000 & .518 & 91.248 \\
\hline & $\mathrm{ME}$ & .412 & .043 & .724 & 9.552 & .000 & & $(0.001)$ \\
\hline \multirow[t]{3}{*}{2} & (Constant) & 1.953 & .175 & & 11.132 & .000 & .598 & 63.554 \\
\hline & $\mathrm{ME}$ & .271 & .052 & .476 & 5.231 & .000 & & \\
\hline & DP & .164 & .039 & .382 & 4.196 & .000 & & \\
\hline \multirow[t]{4}{*}{3} & (Constant) & 1.807 & .169 & & 10.709 & .000 & .649 & 52.849 \\
\hline & $\mathrm{ME}$ & .250 & .049 & .438 & 5.117 & .000 & & $(0.001)$ \\
\hline & DP & .142 & .037 & .332 & 3.851 & .000 & & \\
\hline & $\mathrm{TE}$ & .081 & .023 & .246 & 3.597 & .001 & & \\
\hline \multirow[t]{5}{*}{4} & (Constant) & 1.692 & .174 & & 9.732 & .000 & .664 & 42.524 \\
\hline & $\mathrm{ME}$ & .276 & .049 & .485 & 5.600 & .000 & & $(0.001)$ \\
\hline & DP & .116 & .038 & .270 & 3.033 & .003 & & \\
\hline & $\mathrm{TE}$ & .073 & .022 & .221 & 3.253 & .002 & & \\
\hline & $\mathrm{DM}$ & .048 & .022 & .146 & 2.137 & .036 & & \\
\hline \multirow[t]{6}{*}{5} & (Constant) & 1.503 & .193 & & 7.780 & .000 & .677 & 36.263 \\
\hline & $\mathrm{ME}$ & .261 & .049 & .458 & 5.333 & .000 & & $(0.001)$ \\
\hline & DP & .112 & .038 & .260 & 2.972 & .004 & & \\
\hline & $\mathrm{TE}$ & .071 & .022 & .215 & 3.231 & .002 & & \\
\hline & $\mathrm{DM}$ & .045 & .022 & .139 & 2.067 & .042 & & \\
\hline & $\mathrm{CP}$ & .078 & .038 & .134 & 2.066 & .042 & & \\
\hline \multirow[t]{7}{*}{6} & (Constant) & 1.408 & .194 & & 7.240 & .000 & .691 & 32.290 \\
\hline & $\mathrm{ME}$ & .260 & .048 & .457 & 5.434 & .000 & & $(0.001)$ \\
\hline & DP & .110 & .037 & .257 & 3.004 & .004 & & \\
\hline & $\mathrm{TE}$ & .060 & .022 & .180 & 2.683 & .009 & & \\
\hline & $\mathrm{DM}$ & .041 & .022 & .125 & 1.885 & .063 & & \\
\hline & $\mathrm{CP}$ & .085 & .037 & .146 & 2.291 & .025 & & \\
\hline & $\mathrm{PO}$ & .038 & .018 & .135 & 2.114 & .038 & & \\
\hline
\end{tabular}

a. Dependent Variable: Project Harmony potential

Source: Field survey 2021

\section{CONCLUSIONS AND RECOMMENDATIONS}

\subsection{Conclusions}

Research findings concluded that the project harmony potential was average. Indicating the prevalence of conflicts in the construction projects and the need for identifying the risk areas and assigning them before they grow into conflicts. The study supported the findings by (Morris, M., et al (1998) that the responsibility to review and understand the dynamics of conflict and manage it rests on the project manager. Therefore, the need to lay a focus on the technical experience of the Construction Project Manager considering three key technical areas; academic qualifications, training, and experience in conflict management, ability to use BIM, and project management tools. The research also established the need for utilizing project participants' experience in conflict management gained from past projects and a clear and elaborate communication plan formulated for observation during the entire process of project implementation.

The study established a regression model for evaluating harmony potential using six predictor variables namely; Delay management, Project team partnering orientation, direct provisions of conflict management in the Project Handbook, Promptness of Monitoring and Evaluation, CPM Technical experience, and Clear Communication plan. These factors were found to explain $69.1 \%$ of the project harmony potential for construction projects in Kenya.

\subsection{Recommendations}

The research established that the predictor variables; Delay management, Project team partnering orientation, Direct provisions for conflict management in the Project Handbook, Promptness of Monitoring and Evaluation work, CPM technical experience, and Clear communication plan have a significant influence on the project harmony potential in construction projects in Kenya.

The research, therefore, recommends the following;

(a) To achieve a high project harmony potential level for construction projects in Kenya, greater focus should be on Monitoring, control, and Evaluation, diagnosing the state and nature of any arising conflict to prepare an intervention plan and recommend the best solution as provided in PMBOK $5^{\text {th }}$ edition.

(b) As technical incompetency was considered a major challenge in conflict formulation and therefore conflict management, the right stakeholders have to be selected for the project, the main focus being academic qualifications, training, and experience in conflict management, ability to use BIM, and project management tools.

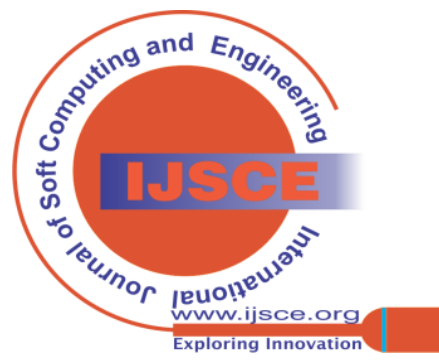


(c) Enough room should be created for the inflow of experiences gained from past projects, by the various stakeholders, towards a project at hand.

(d) A comprehensive diagnosis should involve an assessment of the amount of personal and substantive conflict at the interpersonal, intragroup, and intergroup levels and their sources, and an analysis of relations among them. The results should enable the project managers to identify the problems of conflict, if any, and draw the best type of intervention necessary for managing the conflicts.

(e) Support from the top management in managing conflicts. Change of organizational routine or behavior was ranked as one of the strategies to attaining a greater project harmony potential through conflict management. French and Bell (1999) in Mutungi (2018) suggest that transformational leadership in an organizational culture requires a lot of support from the top management.

(f) The synthesized model framework was developed for managing conflicts in construction projects to be tested. The framework is expected to improve the harmony potential of construction projects in Kenya.

\section{RECOMMENDATION FOR FURTHER STUDY}

(a) The developed model in this research incorporated a segment of the factors believed to affect the potential of project harmony based on the literature reviewed. These factors have been found to account for $69.1 \%$ of the project's harmony potential. A further study should therefore be undertaken to define and include the other factors that account for the remaining $30.9 \%$ of the project harmony potential.

(b) The study defined project harmony to allude to the inverse of a project brimming with conflicts. It would be important to investigate the actual relationship between harmony potential and project performance level.

(c) The study made an assumption that the indicator variables used had equal weighting in defining the project harmony potential. Further study should be conducted to determine the actual weighting for each of these indicator variables of harmony potential.

\section{REFERENCES}

1. Acharya, N. K., Lee, Y. D. and, \& Im, H. M. (2006). Conflicting factors in construction projects: Korean perspective. A Journal of Engineering, Construction and Architectural Management, Vol. 13(6), 543-566.

2. Boddy, D. (2002). Instructor's Manual Second edition.

3. Bryman, A. (2012). Social Research Methods (4th Edn). New York: Oxford University Press.

4. Creswell, J. W. (2009). Research Design: Qualitative, Quantitative and mixed methods approach (2nd Edn). University of Nebraska, Omalla: Sage Publishers.

5. Ejohwomu, A., Oshodi, O., \& Onifade, M. (2016). Causes of Conflicts in Construction Projects in Nigeria: Consultant'S and Contractor'S Perspective. Nigerian Journal of Technology, 35(2), 270. https://doi.org/10.4314/njt.v35i2.6

6. Femi, O. T. (2014). Causes And Effects Of Conflict In The Nigerian Construction Industry. International Journal of Technology
Enhancements and Emerging Engineering Research, Vol 2(6), 2347-4289.

7. Harmon, K. M. J. (2003). Conflicts between Owner and Contractors : Proposed Intervention Process. Management in Engineering Journal, 3(19), 121-125. https://doi.org/10.1061/(ASCE)0742-597X(2003)19

8. Kassab, M., \& Hegazy, T \& Hipel, K. (2010). Computerized DSS for construction conflict resolution uncertainty. Journal of Construction Engineering and Management, Vol 136(12), 1249-1257.

9. Loosemore, M. (2000). Crisis Management in Construction Projects. ASCE Press, American Association of Civil Engineers, 1801 Alexander Bell Drive Reston, Virginia 20191- 4400.

10. Morris, M., Williams, K., Leung, K. et al. (1998). Conflict Management Style: Accounting for Cross-National Differences. Journal of International Business Studies, 29, 729-747. https://doi.org/https://doi.org/10.1057/palgrave.jibs.8490050

11. Mugenda, A. G. (2008). Social Science Research: Theory and Principles. Nairobi: Applied Research \& Training Services.

12. Mutungi. (2018). Factors influencing the practice of resource planning and leveling in the Kenyan construction industry: a survey of contractors in Nairobi county Master of Science (construction project management). Jomo Kenyatta University of Agriculture and Technology.

13. Ntiyakunze, S. K. (2011). Conflicts in Building Projects in Tanzania Analysis of Causes and Management Approaches.

14. Okaka, J. O. (2019). Model for evaluating the performance of construction projects initiated by the constituencies development fund in Kenya: a case study of Siaya county. JKUAT.

15. Puttapalli, A.K. \&Vuram, I. R. (2012). The tool for industrial harmony. International Journal of Multidisciplinary Educational Research, 1(1), 21-43.

16. Talukhaba, A. A. (1999). An Investigation into Factors causing Construction Project Delays in Kenya: Case Study of High Rise Building Projects in Nairobi (Doctrinal Thesis, University of Nairobi).

17. Vaux, J. S. (2014). Relationship conflict in construction managemen and how it affects performance and profit. Washington State University.

18. Wobodo, C. C. (2019). Conflict management strategies and industrial harmony: A theoretical review of Rivers State University, Port Harcourt. The Strategic Journal of Business \& Change Managemen, 6 (2)(May), 981 - 994.

19. Yale, D.J. and Hardcastle, C. (2003). The causes of conflicts and Disputes in the Hong Kong Construction Industry - A Transactional Cost Economics Perspective. Research Papers, Vol. 4(No. 22).

\section{AUTHORS PROFILE}

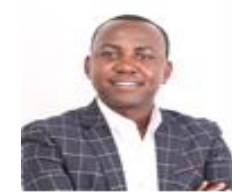

Samuel Kiilu Mbatha: Student, Master in Construction Project Management, Jomo Kenyatta University of Agriculture and Technology (JKUAT), Juja, Kenya.

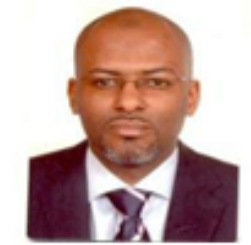

Dr. Ahmad Omar Alkizim, Ph.D. (Reading, UK), MSc. (International Construction Project Mngt, UMIST) BA (Bldg Econ, UON) CIQSK, RQS Specialization: Quantity surveying, Construction Management, Project Management \& Value Engineering.

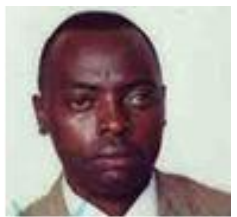

Dr. Titus Kivaa Mbiti, Ph.D. (RMIT, Australia), MA (Bldg Mngt, UON) BA (Bldg Econ, UON) CIQSK, RQS Specialization: Quantity surveying, Construction Management, Project Management \& Construction research.

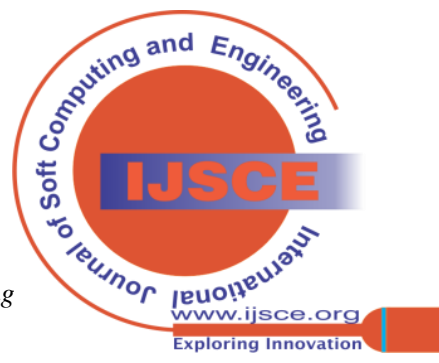

